\title{
POLITIK HUKUM PERLINDUNGAN INDUSTRI DALAM NEGERI INDONESIA DALAM MENGHADAPI PERDAGANGAN BEBAS
}

\author{
Muh. Risnain
}

Dosen Bagian Hukum Internasional Fakultas Hukum Universitas Mataram

\begin{abstract}
Abstrak
Perjanjian internasional di bidang perdagangan inernasional mencakup perjanjian internasional yang bersifat multilateral (WTO), regional (AFTA, ACFTA) maupun bersifat bilateral (RI-Jepang). Berbagai perjanjian internasional tersebut tujuan utamnya adalah liberalisasi perdaganga dimana tidak ada lagi hambatan perdagangan baik bersifat tarif maupun non-tarif. Liberalisasi perdagangan ternyata tidak saja menimbulkan keuntungan bagi sistem perdagangan antar negara, dampak negatifpun berupa bangkrutnya industri nasional merupakan sebuah hal yang tidak terelakan. Untuk itu sebuah negara harus mengambil kebijakan hukum untuk mengambil tindakan dalam melindungi industri dalam negeri. Indonesia mengambil kebijakan Politik hukum melindungi industri dalam negeri dilakukan dengan meletakan prinsip-prinsip dasar perekonomian nasional, baik yang tertera dalam UUD 1945, maupun dalam Undang-undang Nomor 17 tahun 2007 tentang RPJP dan Prolegnas. Politik hukum yang diambil dalam pemerintah dalam melindungi industri dalam negeri dilakukan dengan menjadikan industri nasional memiliki daya saing tinggi dan perlindungan industri dalam negeri dari praktek perdagangan tidak sehat sebagai imbas dari perdagangan internasional yang bebas. Pemerintah dan DPR masih perlu menyempurnakan kebiajakan perlindungan industri dalam negeri melalui penguatan regulasi yang bersifat nasional maupun internasional, kelembagaan dan kepasitas diplomasi perdagangan.
\end{abstract}

Kata Kunci : Politik Hukum, prlindungan hukum, industri dalam negeri.

\section{A. PENDAHULUAN}

Perkembangan $\begin{array}{r}\text { hubungan } \\ \text { internasional }\end{array}$
perdagangan nenara untuk
menyaratkan semua negara
melakukan kerjasama perdagangan
dengan negara lainnya. Hal ini
disadari karena tidak ada satupun
negara dunia ini yang dapat
memenuhi kebutuhannya sendiri
sepenuhnya. Dengan keterbatasan
sumber daya yang dimiliki negara-
negara juga tidak mungkin mereka
mampu memenuhi kebutuhannya.
Sebuah Negara bisa saja
memproduksi tertentu di negara nya,

tetapi dalam waktu yang sama dia pasti membutuhkan produk Negara lain untuk memenuhi kebutuhannya. Indonesia misalkan dengan kekayaan sumber daya alamnya memiliki kemampuan untuk produksi komoditi pertanian seperti kelapa sawit, kakao, cengkeh dll, tetapi dalam waktu yang sama Indonesia membutuhkan produk pertanian Negara lain seperti gandum yang diproduksi Australia untuk memenuhi kebutuhan konsumsi dalam negerinya.

Selain alasan tersebut, perdagangan internasional 
didasarkan pada kehendak Negaranegara untuk mengekspansi produknya di pasar internasional. Walaupun sebuah Negara memiliki memiliki kemampuan untuk memproduksi produk tertentu di negaranya untuk memenuhi kebutuhan domestiknya, negara memiliki kemauan untuk memasarkan produknya di negara lain, tujuannya adalah untuk meraih keuntungan dan menguasai pasar di luar negaranya. Para teoritisi perdagangan internasional mengemukakan berbagai teori tentang perdangan internasional di antaranya adalah teori comparative advantage dari Okler Rohlin,dll.

Hubungan perdagangan internasional tidak terjadi dalam ranah tanpa rambu-rambu, tetapi didasarkan pada ketentuan hukum. Instrumen hukum yang digunakan dalam perdagangan internasional adalah hukum internasional. Lebih khusus lagi adalah perjanjian internasional yang mengikat di antara Negara-negara itu.

Walaupun perdagangan internasional dalam prakteknya terjadi antara perusahaan maupun individu yang ada di masing-masing Negara, namun yang membentuk hukum dan terikat pada hukum adalah Negara. Untuk itu yang ,memiliki tanggung jawab dalam hukum internasional adalah Negara, bukan individu secara langsung. ${ }^{1}$ Indonesia sebagai salah satu negara yang mengandalkan perdagangan internasional sebagai salah satu sumber devisa dan

\footnotetext{
1 Atip Latifulhayat, The Urgent Need for and Models of participation of Private parties in Claims before the World Trade Organization, Jurnal Hukum Internasional UNPAD, Volume I No.1 Tahun 2002, Bandung, 2002
}

kebutuhan akan bahan baku serta kebutuhan untuk memasarkan produknya ke luar negeri terlibat dalam berbagai perjanjian internasional di bidang perdagangan internasional. Keterlibatan Indonesia dalam berbgai perjanjian internasional di bidang perdagangan internasional dilakukan baik dalam bentuk perjanjian bilaterlal, regional dan multilateral.

Perjanjian internasional yang bersifat bilateral dilakukan dengan mengadakan kerjasama antara Indonesia dengan satu egara lain, seperti perjanjian Indonesia dengan Timur tengah di bidang penanaman modal. Perjanjian internasional yang bersifat regional dilakukan Negara Negara-negara se-kawasan seperti Asian Free Trade Area (AFTA) yang mulai berlaku pada tahun 2003.

Namun keterlibatan Indonesia dalam perjanjian internasional di bidang perdagangan selalu diwarnai kontroversi. Ketika Indonesia memutuskan untuk menjadi pihak dalam WTO pada tahun 1994 suara keraguan bahkan penolakan lahir dari suara kampus-kampus dalam bentuk kajian kritis terhadap keputusan tersebut. Pada tahun 2003 ketika AFTA mulai berlaku kekhawatiran pelaku usaha dan dunia kampus juga muncul lagi. Terakhir kasus yang paling disorot public industri adalah keterlibatan Indonesia dalam CAFTA yang telah mulai berlaku sejak 1 Januari 2010 yang lalu.

Keraguan dan penolakan keterlibatan Indonesia dalam berbagai perjanjian internasional di bidang perdagangan setidaknya dilatarbelakangi oleh kekhawatiran. Pertama, dari segi idiologi ekonomi keikutsertaan Indonesia dalam perjanjian perdagangan bebas akan menjadikan Indonesia sebagai salah 
satu Negara yang pro liberalis yang bertentangan dengan ekonomi nasional yang berdasarkan Pancasila. Kedua, kekhawatiran masuknya Indonesia dalam perdagangan internasional akan berimplikasi pada eksistensi Industri dalam negeri yang akan tersingkir dari persaingan perdagangan bebas.

Berdasarkan uraian latar belakang tersebut diatas, maka ditemukan beberapa permasalahan yang hendak dikaji dalam tulisan ini, yaitu bagaimanakah politik hukum yang ditempuh oleh Pemerintah dalam melindungi industri dalam negeri, dan bagaimana kebijakan politik hukum yang tepat yang dapat diambil oleh pemerintah dalam melindungi industri dalam negeri?

\section{B. PEMBAHASAN}

2.1. Telaah teoritis politik hukum dan instrumen hukum perlindungan industri dalam negeri dalam perdagangan internasional

Membahas kajian teoritis tentang politik hukum maka kita dapat menelusuri berbagai pendapat pakah tentang politik Hukum. Berikut ini dikemukakan berbagai pandangan pakar hukum tentang politik hukum. Mochtar Kusumaatmadja $^{2}$ mengemukakan bahwa politik hukum merupakan kebijakan hukum dan perundangundangan dalam pembaharuan hukum. Selengkapanya Mochtar Kusumaatmajda mengatakan bahwa politik hukum di Indonesia :

“ Di Indonesia dimana undangundang merupakan cara

2 Mochtar Kusumaatmadja, pembinaan hukum dalam rangka pembangunan nasional, Bina cipta, Bandung, 1986, hlm.11 pengaturan hukum yang utama pembaharuan hukum terutama melalui perundang-undangan. Proses pembentukan undangundang harus dapat menampung semua hal yang erat hubungannya (relevan) dengan bidang atau masalah hendak diatur dalam undangundang itu, apabila perundangundangan hendak merupakan pengaturan hukum yang efektif. Efektifitas suatu peraturan perundang-undangan dalam penerapannya memerlukan perhatian akan lembaga dan prosedur-prosedur yang diperlukan dalam pelaksanaanya"

Mochtar Kusumaatmadja mengemukakan pula bahwa pembaharuan hukum yang dilakukan melalui instrumen perundangundangan akan mengalami kesulitan dalam dua hal :

Pertama; Kesulitan untuk secara rasional dan pasti menetapkan prioritas yang sesuai dengan kebutuhan masyarakat, dan; Kedua; Untuk membuat hukum yang sesuai dengan kebutuhan dan kesadaran hukum masyarakat Intisari pemikiran politik hukum yang dikemukakan oleh Mochtar Kusumaatmadja adalah berkaitan dengan hukum mana yang perlu dibentuk (diperbaharui, dirubah, atau diganti) dan hukum mana yang perlu dipertahankan agar secara bertahap dapat diwujudkan tujuan negara.

Sunaryati Hartono ${ }^{3}$ dalam buku Politik Hukum Menuju Satu Sistem Hukum Nasional mengemukakan bahwa politik hukum nasional tidak

\footnotetext{
${ }^{3}$ Sunaryati Hartono, Politik Hukum Menuju Satu Sistem Hukum Nasional, Alumni, Bandung, 1991, hlm.19
} 
dapat melepaskan diri dari perkembangan hukum internasional dan hukum Negara lain sebagai bahan perbandingan maupun rujukan dalam memperkaya khasanah hukum nasional.

"cukup banyak peraturan dan kebijakan hukum kita bukanlah semata-mata ditentukan oleh kehendak bangsa kita sendiri, akan tetapi terjadi akibat pengaruh kaidah hukum atau kebijakan yang ditentukan dalam forum internasional atau oleh negara asing. Itulah sebabnya mengapa untuk menghindari pengaruh ini atau untuk menekannya sehingga menjadi sedikit mungkin, maka pembentukan hukum baru kita perlu lebih banya memperhatikan perkembangan hukum internasional atau negara asing. Itulah sebabnya mengapa untuk menghindari pengaruh ini atau untuk menekannya sehingga menjadi sedikit mungkin, maka pembentukan baru hukum kita perlu lebih banyak memperhatikan perkembangan hukum internasional dan perkembangan hukum negara lainlain negara (baik negara maju maupun negara berkembang lainnya).

Moh. Mahfud M.D. ${ }^{4}$ mengartikan politik hukum adalah legal policy atau arah hukum yang akan diberlakukan oleh Negara untuk mencapai tujuan Negara yang bentuknya dapat berupa pembuatan hukum baru dan penggantian hukum lama. Definisi politik hukum tersebut kemudian diperluas lagi dengan memasukkan aspek latar belakang dan lingkungan yang mempengaruhi serta berbagai persoalan yang

\footnotetext{
${ }^{4}$ Moh. Mahfud M.D, Membangun Politik Hukum, Menegakkan Konstitusi, Pustaka LP3ES , Jakarta, 2006, hlm.5
}

dihadapi dalam upaya menegakkannya.

Terkait dengan fokus kajian politik hukum, Mahfud M.D. membagi tiga kelompok dari politik hukum, yaitu: pertama; arah resmi tentang hukum yang akan diberlakukan (legal policy) guna mencapai tujuan Negara yang mencakup penggantian hukum lama dan pembentukkan hukum-hukum yang baru sama sekali, kedua; latar belakang politik dan subsistem kemasyarakatan lainnya dibalik lahirnya hukum, termasuk arah resmi tentang hukum yang akan atau tidak akan diberlakukan, ketiga; persoalanpersoalan disekitar penegakkan hukum, terutama implementasi atas politik hukum yang telah digariskan.

Mahfud juga berpendapat bahwa pijakan yang menjadi landasan dari politik hukum adalah mewujudkan tujuan Negara dan sistem hukum dari Negara yang bersangkutan yang dalam konteks Indonesia tujuan dan sistem hukum itu terkandung di dalam Pembukaan UUD 1945, khususnya Pancasila yang melahirkan kaedah-kaedah penuntun hukum.

Menurut Satjipto Rahardjo politik hukum ${ }^{5}$ adalah aktivitas memilih dan cara yang hendak dipakai untuk mencapai tujuan sosial dan hukum tertentu dalam masyarakat. Untuk mempertajam definisi politik hukum Satjipto Rahardjo mengemukakan beberapa pertanyaan mendasar yang harus dijawab dalam politik hukum : (1) tujuan apa yang hendak dicapai dengan sistem hukum yang ada; (2) cara-cara apa dan yang mana yang dirasa paling baik untuk bias dipakai

\footnotetext{
5 Satjipto Rahardjo, Ilmu Hukum, cet.III, Citra Aditya Bhakti, Bandung, 1991, hlm.352
} 
mencapai tujuan tersebut;(3) kapan waktunya hukum itu perlu dirubah dan melalaui cara-cara bagaimana perubahan itu sebaiknya diakukan dan (4) dapatkah dirumuskan suatu pola yang baku dan mapan yang bisa membantu kita membantu kita melakukan proses pemilihan tujuan serta cara-cara untuk mencapai tujuan tersebut secara baik. Menurut Abdul Hakim Garuda Indonesia dalam makalahnya yang berjudul politik hukum nasional, Abdul Hakim garuda Nusantara memeberikan definisi bahwa politik hukum adalah kebijakan hukum (legal policy) yang hendak diterapkan atau dilaksanakan secara nasional oleh suatu pemerintahan Negara tertentu secara terperinci AHGN mengemukakan beberapa aspek dari politik hukum, yakni : 1 . Pelaksanaan ketentuan hukum yang telah ada secara konsisten; 2. Pembangunan hukum yang intinya adalah pembaharuan terhadapa ketentuan hukum yang telah ada dan yang dianggap usang, dan menciptakan ketentuan hukum baru yang diperlukan untuk memenuhi tuntutan perkembangan yang terjadi didalam masyarakat; 3. Penegasan fungsi lembaga penegak atau pelaksna hukum dan pembinaan anggotanya; dan 4. Meningkatkan kesadaran hukum masyarakat menurut persepsi kelompok elit pengambil kebijakan.

Menurut Imam Syaukani \& Ahsin Thohari ${ }^{6}$, politik hukum adalah kebijakan dasar penyelenggara Negara dalam bidang hukum yang akan, sedang dan telah berlaku, yang bersumber dari nilainilai yang berlaku dimasayarakat

\footnotetext{
${ }^{6}$ Imam Syaukani \& Ahsin Thohari, Dasardasar Politik Hukum, Rajawali Press, Jakarta,2004, hlm.32
}

untuk mencapai tujuan Negara yang dicita-citakan.

a. Instrumen Hukum Perlindungan Industri dalam Negeri

Walaupun perdagangan internasional yang dikehendaki GATT/WTO merupakan perdagangan internasional yang bebas dan kompetitif, namun dalam praktek perdagangan internasional menunjuk kan adanya praktek yang menghambat perdagangan internasional. Kebijakan perdagangan internasional yang cenderung menghambat perdagangan internasional adalah countervailing duty, safeguard, dan antidumping. Ketiga kebijakan perdagangan internasional tersebut dianggap sebagai tiga bentuk rezim penghambat perdagangan (trilogy of trade remedy regimes). ${ }^{7}$

Robber Hudec membedakan dua macam kebijakan pemerintah yang dapat menyebabkan terjadinya kondisi tidak fair dalam perdagangan internasional yaitu, kebijakan yang bersifat offensive unfairness dan defensive unfairness. Kebijakan yang bersifat offensive unfairness yaitu kebijkan negara dalam posisinya sebagai negara eksporter yang menyebabkan terjadinya kondisi persaingan yang tidak sehat pada pasar negara importir atau pasar negara ketiga. Dalam hal kebijakan yang bersifat defensive unfairness adalah kebijakan negara untuk memberikan perlakuan istimewa

\footnotetext{
${ }^{7}$ Michael J Trebilock and Robert Howse, The Regulation of International Trade, Second Edition, Routledge, New York, hlm.166
} 
kepada produk dalam negerinya dan menghukum produk luar negeri yang

masuk ke dalam pasar dalam negerinya. 


\section{Countervailing Duty}

Rezim hukum countervailing duties adalah kewajiban khusus yang dikenakan untuk menghadapi setiap subsidi atau yang diberikan secara langsung maupun tidak langsung terhadap perusahaan, produksi atau ekspor perdagangan. Kebijkan negara untuk menerapkan Countervailing Duties sebagai akibat dari kebijakan subsidi negara lain harus menunjukan bahwa kebijakan subsidi tersebut telah mengakibatkan terjadinya kerugian material (material injury) bagi industri dalam negeri (domestic industri) negara importer, baik industri yang telah ada (an established industri) maupun menghalangi industri yang akan terbentuk (to retard materially the establishment industri). Diperkenankanya kebijakan countervailing duties dalam mengahadapi subsidi dari negara lain didasarkan pada dua alasan utama. ${ }^{8}$

Pertama, alasan efisiensi (efficiency rationales). Secara umum dikatakan subsidi yang dilakukan oleh negara lain memnyebabkan terjadinya kondisi distorsi terhadap keunggulan komparatif (comparative advantage) yang dimiliki oleh suatu negara yang pada akhirnya menciptakan ketidakefisienan dalam alokasi sumber daya ekonomi global (global economomy resources). Selain itu subsidi yang dilakukan oleh negara lain menyebabkan sebuah perusahaan melakukan kebijakan banting harga (predatory pricing) pada pasar luar negerinya. Oleh karena perusahaan tersebut mendapat subsidi dari pemerintah maka perusahaan tersebut menjual produknya dengan harga yang rendah untuk menguasai persaingan dan

\footnotetext{
${ }^{8}$ Ibid
}

pada akhirnya dia memiliki kekuatan memonopoli pasar di negara importir. Kebijakan banting harga baik dalam tataran nasional maupun internsional pada akhirnya menyebabkan terjadinya rendahnya kesejahteraan ekonomi yang diperoleh suatu negara.

Kedua, alasan keadilan dalam perdagangan (Fairness Rationales). Berdasarkan alasan ini subsidi dapat menyebabkan kondisi perdagangan yang tidak fair dan merusak levelplaying field dalam perdagangan internasional. Dalam hal ini countervailing duties merupakan reaksi terhadap kebijakan negara yang bersifat ofensif dengan dasar bahwa perusahaan asing dapat menimbulkan keluarnya industri dalam negeri di arena persaingan karena perusahaan asing menikmati keuntungan dan kemudahan yang didapat dari subsidi pemerintahnya.

\section{Safeguards}

Secara umum safeguards didefinisikan sebagai kebijakan pemerintah negara importir untuk menanggulangi impor dari luar negeri yang dapat mengancam ekonomi dan industri dalam negeri. Mekanisme safeguard dianggap sebagai bentuk pembatasan impor (import-restraining) yang berupa peningkatan tarif, pembatasan kuantitatif, pembatasan sukararela oleh negara eksportir ataupun bentuk kebijakan lainnya. ${ }^{9}$ Kebijakan safeguard merupakan implikasi dari adanya perdagangan bebas yang mereduksi hambatan-hambatan masuknya perdagangan barang dan jasa. Akibat dari liberalisasi perdagangan menyebabkan terjadi-

\footnotetext{
9 John H Jackson, The World Trading Sistem...Op.cit hlm. 149
} 
nya peningkatan ekspor-impor dalam perdagangan internasional. Peningkatan impor kadang-kadang mengancam terjadinya kerugian yang dialami oleh industri dalam negeri negara importir, oleh karena itu negara importir diberikan hak untuk membatasi impor untuk sementara waktu dalam bentuk safeguards. Kebijakan safeguard hanya dapat dilakukan untuk waktu yang terbatas untuk menyelamatkan industri dalam jangka waktu tertentu.

Kebijakan safeguard bukan reaksi terhadap kebijakan perdagangan internasional yang tidak fair yang dilakukan oleh produsen luar negeri, tetapi merupakan kebijakan untuk menyelamatkan industri dalam negeri secara temporer dalam rangka melindungi industri dalam negeri sebagai akibat meningkatnya impor yang dilakukan oleh negara. Dalam safeguard kebijakan perdagangan yang dilakukan oleh negara lain masih dalam situasi persaingan sehat (fair competition). ${ }^{10}$

$\begin{array}{rrr}\text { Menurut } & \text { John } & \text { Jackson }^{11} \\ \text { terdapat dua alasan } & \text { kebijakan }\end{array}$ safeguard itu dapat dilakukan yaitu alasan ekonomi dan alasan pragmatis atau alasan politis. Pertama; alasan penyesuaian ekonomi (economic adjustment), peningkatan import kadang menyebabkan terjadinya kehancuran industri terhadap industri dalam negeri. Oleh karena itu industri dalam negeri diberikan kesempatan untuk menyesuaiakan kondisi perusahaan mereka terhadap masuknya impor barang dari luar negeri, selain itu industri dalam negeri diberikan kesempatan untuk meningkatkan daya saing (competitiveness) termasuk

\footnotetext{
${ }^{10} \mathrm{Ibid}$

${ }^{11}$ Ibid
}

produktivitas, kualitas, dan harga atau dengan jalan memasukan sumber daya produksi menjadi bagian dari proses produksi. Kebijakan safeguard bertujuan untuk menguatkan industri dalam negeri sehingga dapat bersaing dengan produk impor. Kedua; alasan pragmatis atau politis (pragmatic or political argument). Kebijakan safeguard dapat dilakukan karena produsen dalam negeri mempunyai kekuatan untuk mempengaruhi kebijakan pemerintah. Oleh karena produsen dalam negeri dapat mempengaruhi kebijakan importasi pemerintah maka produsen dalam negeri dapat menekan pemerintah untuk mengambil kebijakan untuk memberlakukan kebijakan safeguards terhadap produk asing.

Kebijakan safeguards menurut John Jackson sangat erat kaitanya dengan kebijakan industri (industrial policy) karena jika kebijakan penyesuaian sebagai alasan untuk tindakan melakukan safegauard secara temporer untuk membatasai impor yang diikuti oleh kebijakan pemerintah untuk melakukan penyesuian untuk kebijakan industri dalam negeri negara importer. Kebijakan seperti ini pernah sukses dilakukan oleh Jepang dan Amerika dalam kebijakan program industri mereka.

\section{Antidumping}

Menurut John H. Jackson dumping adalah penjualan barang ke pasar ekspor lebih rendah dari harga atau ongkos jika barang tersebut dijual di pasar negara pengekspor (home-market). ${ }^{12} \quad$ Dalam kamus Black Law Dictiniory, Dumping

\footnotetext{
12 John H. Jackson, et Legal Problems Op.cit hlm.669
} 
diartikan sebagai" the act of selling a large quantity of goods at less than fair value" atau " selling goods abroad at less than the market price home" ${ }^{\text {13 }}$ Umumnya dumping adalah bentuk diskriminasi harga internasional yang dilakukan oleh sebuah perusahaan atau negara pengekspor yang menjual barangnya dengan harga lebih rendah di pasar luar negeri dibandingkan dengan pasar dalam negeri sendiri dengan tujuan memperoleh keuntungan yang sebesar-besarnya atas produk tertentu ${ }^{14}$.Dalam pandangan ilmu ekonomi dumping diartikan " Dumping is traditionally defined as selling at a lower price in one national market than in another" Menurut Folshom dumping dikatakan sebagai,

“...dumping involves selling abroad at a price that it less than the price used to sell the same goods at home (the normal or fair value).to be unlawfull, dumping must threaten or causal material injury to an industri in the export market, the market where price are lower.

Dumping is recognized by most of trading world as an unfair practice (against to price discrimination as an antitrust offense)". 15

Berdasarkan pengertian di atas maka dapat dikatakan bahwa dumping adalah menjual produk ke luar negeri dengan harga yang lebih

${ }^{13}$ Bryan A Garner, Black Law Dictionary, Seventh edition, Dallas Texas, 1999 hlm. 518

${ }^{14}$ Sri Sukarmi, Regulasi..., Op. Cit. hlm.25

${ }^{15}$ Ralph H. Folsom and Michael W Gordon, International Bussiness Transactions, Handbook series, West publishing, Co. ST. Paul, Minn, 1995, hlm.127 murah dibandingkan dengan penjualan produk tersebut di negara sendiri yang berada di bawah nilai normal. Nilai normal dapat diartikan sebagai harga untuk produk yang sama yang dijual di negara sendiri atau pengekspor. Dalam persetujuan Uruguay round sebagaimana ditentukan dalam Pasal VI GATT ayat (2) bahwa praktek suatu negara dikatakan sebagai dumping jika ${ }^{16}$ : "...for the purpose of this agreement, a product is dumping,i.e, introduced into the commerce of another country at less that its normal value, if the export price of the product exported from one country to another is less than the comparable price, in the ordinary course of trade, for like product when destined for consumption in exporting country".

Ketentuan sebagaimana tersebut di atas menentukan bahwa dumping adalah menjual barang di negara lain kurang dari nilai normalnya. Apabila harga ekspor produk yang diekspor dari satu negara ke negara lain kurang dari harga pembanding (comparable price) dalam perdagangan yang biasa, bagi produk sejenis (like product) itu untuk tujuan konsumsi di negara pengekspor.

Tindakan Dumping dalam perdagangan internasional dianggap sebagai tindakan yang bertentangan dengan semangat persaingan dagang yang adil sebagaimana yang dikehendaki GATT/WTO. Perdagangan bebas (free trade) menghendaki adanya persaingan yang adil antara negara dalam

\footnotetext{
${ }^{16}$ Pasal 2 Aggreement on Implementation of Article VI of GATT 1994.
} 
melakukan aktivitas perdagangan. Artinya, bahwa perdagangan bebas tidak menghedaki adanya kebijakan pelaku usaha yang merugikan pelaku usaha lain dalam melakukan aktivitas perdagangan, tetapi harus mendapat keuntugan dari aktivitas perdagangan yang bebas itu.

Kebijakan antidumping merupakan reaksi dari negara yang merasa dirugikan oleh kebijakan penjualan perusahaan negara lain yang melakukan praktek dumping. Praktek dumping merupakan pratek perdagangan internasional yang tidak adil. Menurut black Law dictinory, antidumping adalah tariff, purposes of which to prevent imports of goods for sale at lower price that charged in coutry of origin $^{17}$. Rumusan ini menunjukkan bahwa kebijakan antidumping merupakan langkah negara importir untuk mencegah terjadinya akibat negatif dari penjualan barang dengan harga dumping dari negara lain.

\subsection{Politik Hukum Perlindungan Industri Dalam Negeri Dalam Menghadapi Perdagangan Bebas}

\section{a. Politik Hukum Ekonomi Nasional}

Membahas politik hukum perindungan industri dalam negeri dalam perdagangan internasional maka tidak terlepas dari landasan konstitusi politik ekonomi nasional. Dalam konteks Indonesia pembahasan Pasal 33 Undangundang Dasar 1945 merupakan landasan konstitusi dalam pembangunan ekonomi nasional. Dengan berdasarkan pada Pasal 33

17 Henry Cambbell Black, Black Law Dictionary, West Publishing, 1991
UUD 1945 tersirat bahwa pembangunan ekonomi nasional yang hendak dicapai haruslah berdasarkan pada demokrasi ekonomi yang bersifat kerakyatan yaitu terciptanya keadilan sosial bagi seluruh rakyat Indonesia. ${ }^{18}$ Di samping itu Pasal 33 UUD 1945 tersebut memberikan petunjuk bahwa roda perekonomian nasional tidak dibiarkan begitu saja kepada pasar tetapi harus ada intervensi pemerintah yang mengatur aturan main (rule of the game) dalam menjalankan perekonomian nasional dalam bentuk peraturan perundangundangan.

Menurut Sri Edi Swasono ${ }^{19}$
frasa "Perekonomian disusun..."
dalam kalimat Perekonomian
disusun sebagai usaha bersama berdasarkan asas kekeluargaan yang terdapat dalam Pasal 33 ayat (1) UUD 1945 mengandung pengertian imperatif, artinya bahwa perekonomian nasional tidak dibiarkan berjalan sendiri atau mengikuti kekuatan-kekuatan yang ada atau kekuatan pasar bebas. Perkataan "disusun" mengisyaratkan adanya upaya membangun secara struktural perekonomian nasional melalui tindakan nyata. Tugas penyusunan bangunan ekonomi nasional tersebut merupakan kewajiban negara.

\footnotetext{
18 Ayudha D. Prayoga, Dkk, Persaingan Usaha dan Hukum yang Mengaturnya di Indonesia, Partnership for Business Competition, Jakarta, 2001, hlm.117

19 Sri-Edi Swasono, Demokrasi Ekonomi: Keterkaitan usaha partisipatif Vs. Konsentrasi Ekonomi, Makalah dalam seminar "Pancasila sebagai Ideologi dalam Berbagai Bidang kehidupan Bermasyarakat, Berbangsa dan Bernegara”, yang diselenggarakan B-7 Jakarta, 24 Oktober 1989, hlm.17 sebagaimana terkutip dalam Ayudha D Prayoga Dkk, ibid.
} 
Keterlibatan pemerintah dalam mengatur ekonomi nasional dimaksudkan sebagai usaha untuk menghindari terjadinya suatu kondisi free fight liberalism, etatisme, persaingan tidak sehat serta pemusatan kekuatan ekonomi pada satu kelompok dalam berbagai bentuk monopoli dan monopsoni yang merugikan masyarakat dan bertentangan dengan cita-cita keadilan sosial. $^{20}$

Ketiga kondisi di atas merupakan suatu kondisi ekstrim yang tidak dikehendaki oleh semangat perekonomian nasional yang demokratis yang melindungi eksistensi semua kelompok dalam aktifitas ekonomi. Kelompok yang cenderung terkena imbas kondisi di atas adalah kelompok usaha yang berada dalam posisi yang lemah.

Pasca bergulirnya reformasi bangunan ekonomi nasional diperkuat kembali dengan ketentuan yang terdapat dalam Pasal 33 ayat (4) yang merupakan ketentuan tambahan terhadap Pasal 33 UUD 1945 yang berbunyi sebagai berikut:

$\begin{array}{rr}\text { "Perekonomian } & \text { nasional } \\ \text { diselenggarakan } & \text { atas }\end{array}$ demokrasi ekonomi dengan prinsip kebersamaan, efisiensi, berkeadilan, berkelanjutan, berwawasan lingkungan, kemandirian, serta dengan menjaga keseimbangan kemajuan dan kesatuan ekonomi nasional ${ }^{, 21}$

Penegasan pencantuman prinsip-prinsip kebersamaan, efisiensi, berkeadilan, berkelanjutan, berwawasan lingkungan, kemandirian, serta dengan menjaga keseimbangan kemajuan dan

${ }^{20}$ Baca GBHN 1993-1998

21 Amandemen keempat Undang-Undang Dasar 1945 kesatuan ekonomi pada ayat (4) di atas merupakan jalan tengah terhadap adanya tuntutan yang berkembang dalam masyarakat yang menghendaki asas kekeluargaan dalam Pasal 33 Ayat (1) UUD 1945 dihapus dengan berdasarkan kenyataan bahwa kata "kekeluargaan" dimanfaatkan oleh kelompok tertentu untuk menguasai sumber ekonomi nasional. ${ }^{22}$ Berdasarkan Pasal 33 UUD 1945 terlihat jelas bahwa politik ekonomi nasional didasarkan pada prinsipprinsip demokrasi ekonomi yang mengandung ekonomi berkeadilan.

Dalam politik hukum kedudukan Undang-undang Dasar ibarat "ibu kandung" yang melahirkan produk hukum yang dilahirkan kemudian. Peraturan perundang-undangan pelkasana yang lahir kemudian dan telah dahulu lahir semuanya harus merujuk kepada konstitusi sebagai sumber hukum tertinggi. Dalam politik hukum ekonomi nasional, Pasal 33 merupakan ibu kandung dari semua aturan yang berkaitan dengan aktifitas ekonomi nasional.

Namun demikian tidak dapat dipungkiri bahwa globalisasi dunia yang dimotori oleh liberaliralisasi perdagangan merupakan suatu hal yang tidak dapat kita hindari. Sebagai bagian dari masyarakat internasional yang melakukan interaksi dalam dengan masyarakat internasional maka interaksi ekonomi pun merupakan sebuah keniscayaan yang tidak dapat kita elakkan. Globalisasi dan liberalisasi tidak hadir dengan sendirinya, tetapi

22 Jimly Asshidiqie, Konsolidasi Naskah UUD 1945 setelah Perubahan Keempat, Pusat studi Hukum Tata Negara Fakultas Hukum Universitas Indonesia, Jakarta, 2002, hlm.57 
didukung oleh berbagai sistem hukum yang mendukungya. Instrumen hukum pendukung liberalisasi antara lain adalah perjanjian pembentukan WTO, Perjanjian AFTA dan CAFTA.

\section{b. Politik Hukum Pengesahan Perjanjian Internasional di bidang Perdagangan}

Perjanjian internasional di bidang perdagangan yang disebutkan di atas adalah bentuk perjanjian internasional yang membetuk hukum (law making treatis) yang berimplikasi pada lahirnya hak dan kewajiban bagi negara. ${ }^{23}$ Ketika Indonesia hendak terlibat dalam perjanjian internasional maka harus dicari landasan filosofis dan dasar konstitusional sebagai landasan hukum terlibatnya Indonesia dalam perjanjian internasional. Pasal 11 UUD 1945 menentukan bahwa :

1. Presiden dengan persetujuan Dewan Perwakilan Rakyat menyatakan Perang, membuat perdamaian dan perjanjian dengan orang lain.

2. Presiden dalam membuat perjanjian internasional lainnya yang menimbulkan akibat yang luas dan mendasar bagi kehidupan rakyat yang terkait dengan beban keuangan Negara, dan/atau mengharuskan perubahan atau pembentukan undang-undang harus dengan persetujuan dewan perwakilan rakyat.

Ketentuan Pasal 11 di atas menjadi landasan politik hukum

${ }^{23}$ Yudha Bhakti ardiwisastra, Bunga Rampai Hukum Internasional, Alumni, Bandung, 2003 pengesahan perjanjian internasional oleh pemerintah Indonesia. Indonesia meletakan bahwa perjanjian internasional merupakan instrument hukum yang penting dalam membangun kerjasama internasional dengan Negara dan subjek internasional lainnya. ${ }^{24}$ Disadari pula oleh pembentuk UUD bahwa perjanjian internasional tidak hanya melahirkan kewajiban Negara yang bersifat politis semata, tetapi lebih dari itu bahwa perjanjian internasional merupakan instrument hukum yang membawa impikasi besar bagi kehidupan bangsa Indonesia. $^{25}$

Telah ditegaskan dalam konstitusi bahwa perjanjian internasional yang menimbulkan akibat yang luas dan mendasar bagi kehidupan rakyat yang terkait dengan beban keuangan Negara, dan/atau mengharuskan perubahan atau pembentukan undang-undang harus mendapatkan persetujuan dari rakyat Indonesia melalui wakilnya di DPR.

Perjanjian internasional yang disahkan Indonesia melalui mekanisme hukum nasional baik melalui Undang-undang maupun Peraturan Presiden tidak hanya berimplikasi lahirnya hak dan kewajiban hukum yang berdasarkan hukum nasional, tetapi juga berimplikasi pada aspek keuangan negara dan adanya kewajiban untuk harmonisasi hukum nasional.

Dalam konstitusi telah ditentukan pula bahwa implikasi hukum yang akan timbul dari perjanjian internasional adalah perubahan atau pembentukan

24 Bagir Manan, Pertumbuhan dan Perkembangan Konstitusi Suatu Negara, Mandar Maju, Bandung, 1995, hlm.93 25 Harjono, Politik Hukum Perjanjian Internasional, Bina Ilmu, Surabaya, 1996 
undang-undang. Disinilah terlihat dengan jelas bagaimana pengaruh perjanjian internasional terhadap pembentukan hukum nasional, untuk itu politik hukum yang mendasari pengesahan perjanjian internasional oleh pemerintah dan DPR harus jelas ditentukan alasan-alasan yang melatar belakanginya.

Terkait dengan bagaimana pengaruh hukum internasional dalam politik hukum nasional ada baiknya kita mengemukakan pandangan Sunaryati Hartono "cukup banyak peraturan dan kebijakan hukum kita bukanlah semata-mata ditentukan oleh kehendak bangsa kita sendiri, akan tetapi terjadi akibat pengaruh kaidah hukum atau kebijakan yang ditentukan dalam forum internasional atau oleh negara asing. Itulah sebabnya mengapa untuk menghindari pengaruh ini atau untuk menekannya sehingga menjadi sedikit mungkin, maka pembentukan hukum baru kita perlu lebih banya memperhatikan perkembangan hukum internasional atau negara asing".

Pandangan ini menegaskan kembali bahwa dalam pembentukan hukum nasional kita tidak dapat menghindarkan diri dari pengaruh hukum internasional dan hukum Negara asing dalam pembentukan hukum nasional. Keterkaitan hukum nasional pada hukum internasional merupakan sebuah keniscayaan di era globalisasi ini. Kelihaian kita sebagai sebuah bangsa untuk menakar bagaimana dampak yang lahir dari perjanjian internasional itu terhadap kepentingan nasional kita sangat diperlukan. Jika perjanjian internasional itu membawa dampak hukum yang menguntungkan Indonesia baik dalam konteks nasional maupun dalam konteks hubungan internasional maka sebaiknya kita pertimbangkan untuk terlibat di dalamnya. Namun, jika pengesahan perjanjian internasional merugikan kepentingan nasional dan dunia internasional maka perlu juga sebaiknya dipertimbangkan untuk tidak terlibat di dalamnya.

Landasan politik hukum pengesahan perjanjian internasional yang patut kita rujuk dalam proses pengesahan perjanjian internasional adalah Undang-Undang Nomor 24 Tahun 2000 tentang Perjanjian Internasional. Ketentuan Pasal 3 menyatakan bahwa prinsip dasar dalam setiap pengesahan perjanjian internasional adalah memperhatikan kepentingan nasional dan kepentingan hukum internasional. Ketentuan ini terlihat ada kontradiksi yang terkandung di dalamnya karena menyandingkan kepentingan nasional dan kepentingan internasional merupakan suatu hal yang tidak logis. Namun ketentuan ini dapat dijadikan landasan bagi politik hukum yang diambil pemerintah dan parlemen dalam setiap kebijakan untuk mengesahkan perjanjian internasional. Dasar kita untuk mengesahkan perjanjian internasional tetap didasarkan pada kepentingan nasional, tetapi di sisi lain ketika kita telah menjadi pihak di dalamnya maka sesuai dengan prinsip itikad baik dan pacta sun servanda dalam hukum internasional maka kita harus tunduk secara penuh (full comply) kepada perjanjian internasional.

Dengan dasar politik hukum yang telah digariskan dalam konstitusi dan Undang-Undang Nomor 24 Tahun 2000 tentang Perjanjian Internasional maka politik hukum pengesahan perjanjian internasional yang memberikan 
perlindungan industri dalam negeri telah jelas arah kebijakannya. Sebagaimana telah diuraikan di muka dalam konteks liberalisasi perdagangan internasional Indonesia telah terlibat dalam berbagai perjanjian internasional yaitu persetujuan pembentukan WTO melalui Undang-Undang Nomor 7 Tahun 1994 yang didalamya mengatur berbagai instrumen hukum yang dapat digunakan oleh Pemerintah Indonesia untuk melindungi industri dalam negerinya baik yang sebagai akibat dari praktek perdagangan tidak sehat (unfair trade competition) seperti dumping, subsidi, maupun ketidakmampuan negara dalam menghadapi persaingan, safeguard.

\section{c. Politik Hukum Perlindungan Industri dalam Negeri dalam RPJP 2005-2025}

Untuk melihat politik hukum perlindungan industri dalam negeri, maka fokus kajian kita tidak akan lepas dari bagaimana kebijakan hukum yang mendasari kebijakan pembangunan nasional. Dalam sistem pembangunan nasional Indonesia kebijakan dan politik pembangunan nasional dituangkan dalam bentuk Rencana Pembangunan Jangka Panjang. Menurut Pasal 3 Undang-Undang Nomor 17 Tahun 2007 tentang Rencana Pembangunan Jangka Panjang diuarikan bahwa RPJP dalam politik pembangunan nasional adalah :

"RPJP Nasional merupakan penjabaran dari tujuan dibentuknya Pemerintahan Negara Indonesia yang tercantum dalam Pembukaan Undang-Undang Dasar Negara Republik Indonesia Tahun
1945, yaitu untuk melindungi segenap bangsa dan seluruh tumpah darah Indonesia, memajukan kesejahteraan umum, mencerdaskan kehidupan bangsa, dan ikut melaksanakan ketertiban dunia yang berdasarkan kemerdekaan, perdamaian abadi, dan keadilan sosial dalam bentuk rumusan visi, misi dan arah Pembangunan Nasional"

Merujuk pada ketentuan di atas dapat dikatakan bahwa RPJP merupakan cerminan dari politik pembangunan yang hendak mewujudkan tujuan kehidupan berbangsa dan berbangsa dan negara yang tertuang dalam pembukaan undang-undang dasar 1945. Dari RPJP kita juga dapat melihat bagaimana politik hukum dan sebuah program pembanguan yang akan ditempuh dalam jangka waktu 20 tahun kedepan.

Dalam konteks politik pembagunan hukum nasional RPJP telah meletakan landasan dasar politik hukum nasional yang diarahkan pada program reformasi hukum dan birokrasi. Secara lengkap RPJP menetapkan politik pembangunan hukum kita pada dua hal, yaitu :

1. Pembangunan hukum diarahkan untuk mendukung terwujudnya pertumbuhan ekonomi yang berkelanjutan; mengatur permasalahan yang berkaitan dengan ekonomi, terutama dunia usaha dan dunia industri; serta menciptakan kepastian investasi, terutama penegakan dan perlindungan hukum. Pembangunan hukum juga diarahkan untuk menghilangkan kemungkinan terjadinya tindak 
pidana korupsi serta mampu menangani dan menyelesaikan secara tuntas permasalahan yang terkait kolusi, korupsi, nepotisme (KKN). Pembangunan hukum dilaksanakan melalui pembaruan materi hukum dengan tetap memerhatikan kemajemukan tatanan hukum yang berlaku dan pengaruh globalisasi sebagai upaya untuk meningkatkan kepastian dan perlindungan hukum, penegakan hukum dan hak-hak asasi manusia (HAM), kesadaran hukum, serta pelayanan hukum yang berintikan keadilan dan kebenaran, ketertiban dan kesejahteraan dalam rangka penyelenggaraan negara yang makin tertib, teratur, lancar, serta berdaya saing global.

2. Pembangunan aparatur negara dilakukan melalui reformasi birokrasi untuk meningkatkan profesionalisme aparatur negara dan untuk mewujudkan tata pemerintahan yang baik, di pusat maupun di daerah agar mampu mendukung keberhasilan pembangunan di bidang-bidang lainnya.

Arah politik pembagunan hukum di atas jika kita cermati memiliki hubungan atau korelasi erat dengan pembangunan ekonomi, dunia usaha dan Industri. Masalah pembangunan hukum dan ekonomi dan pembagunan industri bagaikan dua sisi mata uang yang tidak terpisahkan. Pembangunan ekonomi dan pembangunan industri nasional akan sukses tergantung pada pembangunan hukum nasional. Dalam konteks ini pembentukan norma hukum baik hukum nasional maupun hukum internasional harus mendukung pembangunan ekonomi, dunia usaha dan industri.

Walaupun demikian dalam pembentukan hukum yang mengatur pembangunan ekonomi dan industri nasional tidak dapat memisahkan diri untuk memberikan perlindungan terhadap industri dalam negeri sebagai motor utama penggerak ekonomi nasional. Hal ini penting dalam perkembangan perdagangan dan ekonomi internasional globalisasi dan liberalisasi perdagangan merupakan sebuah keniscayaan yang harus kita hadapi. Persaingan perdagangan baik yang dilakukan dengan cara-cara fair competition maupun unfair competition merupakan dampak ikutan dari liberalisasi perdagangan.

Mengantisipasi hal tersebut maka Pemerintah harus berani mengambil kebijakan untuk membuat aturan hukum nasional maupun terlibat dalam perjanjian internasional yang mengatur secara spesifik bagaimana mekanisme melindungi industri dalam negeri dari praktek-praktek perdagangan internasional baik yang bersifat fair competition maupun unfair competition.

Sampai saat ini kita telah mengikatkan diri dalam berbagai perjanjian internasional yang mengatur liberlisasi perdagangan internasional antara lain :

1. perjanjian pembentukan WTO melalui Undang-Undang Nomor 7 tahun 1994

2. Persetujuan Kerangka Kerja mengenai Kerjasama Ekonomi Menyeluruh antar Pemerintah Negara-Negara Anggota Perhimpunan Bangsa-Bangsa Asia Tenggara dan Republik Korea (Framework Agreement on Comprehensive Economic 
Cooperation among the

Governments of the Member Countries of the Association of

Southeast Asian Nations and the Republic of Korea) melaui Peraturan Presiden Republik Indonesia Nomor 11 Tahun 2007;

3. Peraturan Presiden Republik Indonesia Nomor 12 Tahun 2007 Tentang Pengesahan Agreement On Trade In Goods Under The Framework Agreement On Comprehensive Economic Cooperation Among The Governments of The Member Countries of The Association Of Southeast Asian Nations And The Republic Of Korea (Persetujuan Perdagangan Barang Dalam Persetujuan Kerangka Kerja Mengenai Kerjasama Ekonomi Menyeluruh Antar Pemerintah Negara-Negara Anggota Perhimpunan Bangsa-Bangsa Asia Tenggara Dan Republik Korea)

4. Peraturan presiden republik indonesia Nomor 18 tahun 2008 Tentang Pengesahan agreement on trade in services of the framework Agreement on comprehensive economic cooperation between The association of southeast asian nations and the people's Republic of china (persetujuan perdagangan jasa dalam Persetujuan kerangka kerja mengenai kerja sama Ekonomi menyeluruh antara negara-negara Anggota asosiasi bangsa-bangsa asia Tenggara dan republik rakyat china)

\subsection{Kebijakan Politik Hukum Yang Tepat Dalam Melindungi Industri Dalam Negeri}

Dalam menemukan konsep kebijakan hukum yang tepat dalam melindungi industri dalam negeri untuk mengahdapi perdagangan bebas maka pijakan politik hukum yang kita tempuh tidak akan lepas dari fondasi dasar perekonomian kita yaitu ekonomi pancasila dan Pasal 33 UUD 1945. Kedua hal tersebut merupakan dasar untuk menentukan cita hukum dalam menentukan kebijakan perlindungan industri dalam negeri.

Keadilan sosial yang terdapat dalam pancasila merupakan fondasi dasar bagi bangsa kita untuk menyusun ekonomi nasional. Pancasila harus dijadikan metanorm dalam menentukan setiap kebjiakan hukum yang mengatur tentang perekonomian nasional, baik dalam konteks regulasi yang bersifat nasional maupun perjanjian internasonal yang dikuti Indonesia dalam rangka perdagangan bebas. Walaupun, kadang-kadang antara perdagangan internasional yang mengusung persaingan bebas dan ekonomi pancasila yang membolehkan masuknya Negara dalam intervensi pasar terjadi kontradiksi,dalam era perdagangan bebas sekarang ini sistem ekonomi pancasila masih tetap relevan dijadikan landasan pembangunan ekonomi nasional.

Ekonomi kerakyatan yang terdapat dalam pasal 33 UUD 1945 merupakan nilai dasar yang dijadikan dasar pula dalam membangun ekonomi nasional. Sejalan dengan pendapat yang disampaikan Prof. Yudha Bhakti Ardiwisastra di atas 
bahwa poltik hukum nasional salah satu tujuannya adalah untuk melindungi segenap bangsa dan selurh tumpah darah Indonesia maka dalam proses penentuan kebijakan hukum perlindungan industri dalam negeri harus memperhatikan aspek perlindungan industri dalam negeri oleh pemerintah sebagai bentuk perlindungan Negara terhadap rakyatnya dari praktek perdagangan cuarang Negara lain.

Secara praktis bahwa politik hukum yang tepat yang dapat ditempuh pemerintah dalam melindungi industri dalam negeri adalah : pertama, memperkuat hukum nasional yang memberikan keberpihakan kepada perlindungan hukum yang seimbang dan proporsional kepada industri dalam negeri dari praktek perdagangan curang Negara lain. Kedua, memperkuat diplomasi pemerintah ketika melakukan negosiasi dengan Negara lain maupun organisasi internasional sehingga dapat memberikan perlindungan hukum yang efektif dan maksimal bagi industri dalam negeri Indonesia, dan ketiga, memperkuat kelembagaan nasional yang dapat memberikan perlindungan industri dalam negeri.

\section{PENUTUP}

Politik hukum yang ditempuh oleh pemerintah dalam melindungi industri dalam negeri dilakukan dengan meletakan prinsip-prinsip dasar perekonomian nasional, baik yang tertera dalam UUD 1945, yang kemudian dimasukan dalam Undangundang Nomor 17 tahun 2007 tentang RPJP dan dalam Prolegnas. Inti dari semua itu adalah adanya kehendak politik bagi pemerintah untuk menjadikan industri nasional memiliki daya saing yang tinggi dan perlindungan industri dalam negeri dari praktek perdagangan tidak sehat sebagai imbas dari perdagangan internasional yang bebas. Walaupun demikian pemerintah dan DPR masih perlu menyempurnakan kebiajakan perlindungan industri dalam negerinya melalui penguatan regulasi yang bersifat nasional maupun internasional, kelembagaan dan kepasitas diplomasi perdagangan. Semua itu dilakukan demi terwujudnya industri nasional yang mampu bersaing dan terlindungi dari perdagangan curang Negara lain.

\section{DAFTAR PUSTAKA}

\section{Buku :}

Ayudha D. Prayoga, Dkk, Persaingan Usaha dan Hukum yang Mengaturnya di Indonesia, Partnership for Business Competition, Jakarta, 2001.

Bagir Manan, Pertumbuhan dan Perkembangan Konstitusi Suatu Negara, Mandar Maju, Bandung, 1995.

Bintan R Saragih, Politik Hokum, Cv. Utomo, Bandung, 2006

Harjono, Politik Hukum Perjanjian Internasional, Bina Ilmu, Surabaya, 1996.

Hutton dan Trebilock, An empirical study of Canadian Antidumping Laws : A Search for Normative Rationales, Routledge, New York.

Jimly Asshidiqie, Konsolidasi Naskah UUD 1945 setelah Perubahan Keempat, Pusat studi Hukum Tata Negara Fakultas Hukum Universitas Indonesia, Jakarta, 2002. 
Mochtar Kusumaatmadja,

Pembinaan Hokum Dalam Rangka Pembangunan Nasional, Bina Cipta, Bandung, 1986

Michael J Trebilock and Robert Howse, The Regulation of International Trade, Second Edition, Routledge, New York.

Moh. Mahfud M.D, Membangun Politik Hukum, Menegakkan Konstitusi, Pustaka LP3ES, Jakarta, 2006.

Padmo Wahjono, Indonesia Negara Berdasar Atas Hukum, Ghalia Indonesia, Jakarta, 1986.

Ralph H. Folsom and Michael W Gordon, International Bussiness Transactions, Handbook series, West publishing, Co. ST. Paul, Minn, 1995.

Satjipto Rahardjo, Ilmu Hukum, cet. III, Citra Aditya Bhakti, Bandung, 1991.

Solly Lubis, Serba-serbi politik dan Hukum, Mandar Maju, Bandung, 1992

Sunaryati Hartono, Politik Hokum Menuju Satu Sistem Hokum Nasional, Alumni, Bandung, 1991.

Yudha Bhakti ardiwisastra, Bunga Rampai Hukum Internasional, Alumni, Bandung, 2003

\section{Jurnal dan Makalah}

Atip Latifulhayat, The Urgent Need for and Models of participation of Private parties in Claims before the World Trade Organization, Jurnal Hukum
Internasional UNPAD, Volume I No.1 Tahun 2002, Bandung.

Bryan A Garner , Black Law Dictionary, Seventh edition, Dallas Texas, 1999.

EC Commission, Eleventh Annual Report On The Community,s Anti-Dumping and Antisubsidy Activities, 1993

Henry Cambbell Black, Black Law Dictionary, West Publishing, 1991

Sri-Edi Swasono, Demokrasi Ekonomi: Keterkaitan usaha partisipatif Vs. Konsentrasi Ekonomi, Makalah dalam seminar "Pancasila sebagai Ideologi dalam Berbagai Bidang kehidupan Bermasyarakat, Berbangsa dan Bernegara”, yang diselenggarakan B-7 Jakarta, 24 Oktober 1989

\section{Undang-undang dan Perjanjian Internasional}

Undang-undang dasar 1945

Undang-undang Nomor 24 tahun 2000 tentang Perjanjian Internasional

Undang-undang Nomor 10 tahun 2004 tentang Pembentukan Peraturan Perundag-undangan

Undang-undang Nomor 17 tahun 2007 tentang RPJP

Keputusan Dewan Perwakilan Rakyat Nomor :41A/DPR $\mathrm{RI} / \mathrm{I} / 2009-2010 \quad$ tentang Persetujuan Penetapan Program Legislasi Nasional Tahun 2010-2014.

Aggreement on Implementation of Article VI of GATT 1994 